
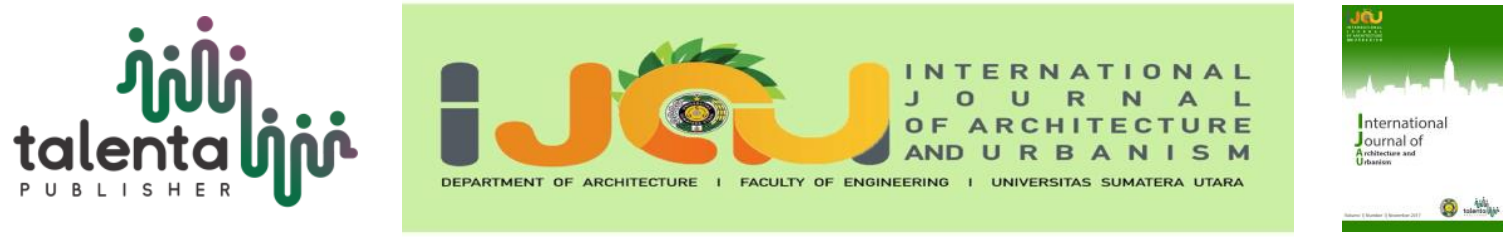

\title{
Designing Public Library of Binjai City by Metaphorical Architecture
}

\author{
Imam Faisal Pane ${ }^{1 *}$, Febrina ${ }^{1}$ \\ ${ }^{1}$ Architecture Department, Faculty of Engineering, Universitas Sumatera Utara, Medan, Indonesia
}

\begin{abstract}
The lack of public reading interest makes people rarely come to visit the public library. The public library of The Binjai city as a media to increase people's knowledge, in fact, that still using traditional planning and structuring and has a less comfortable atmosphere. The Binjai city public library requires to improve its facilities and infrastructures related to the standards of a public library, so that possible to increase people's interest in visiting the library. The designer can make several alternative approaches to design an object, one of that is a metaphorical approach. Choosing of metaphor theme is a theme approachment by taking the book as a visual form that applicated to an element of the building. The strong Malay culture of Binjai city as a local heritage can be applicated in designing the public library of Binjai City. The concept design of the Binjai City Public Library is applied to accommodate library services and activities. By taking a representation physical form of the book as part of the building construction, giving all facilities and services can be functioned to attract more people's attention to visit the library.
\end{abstract}

Keyword: library, metaphor, reading interest

\section{Introduction}

Reading not become a culture among Indonesian people. In 2011, UNESCO released a survey that reading the culture of people among ASEAN countries. Reading culture in Indonesia has the lowest ranking, with a value of 0.001. It means about a thousand Indonesians, only one person has a high reading culture [1]. It can describe that Indonesia still has a low interest in reading.

Indonesia still has a low interest in reading due to language factors, the presence of oral culture in some communities, high book prices, uneven book distribution, the physical form of books, low reading capability, low reading habits and book publishing in Indonesia [2].

Reading interest, books, and libraries are three main elements in the education system to create quality human resources. A nation that has high human resources will be more superior compared to a nation that has high natural resources [3]. The community with a low interest in

\footnotetext{
*Corresponding author at : Departement of Architecture, Faculty of Engineering, University of North Sumatra, Jalan Perpustakaan Building J07, Medan 20155, Indonesia

E-mail address: imamfpane@gmail.com
} 
reading can affect the quality of education and human resources. The public library can play a role in facilitating reading activities and to improve the quality of education and human resources.

Library as an education facility, in fact, people of Binjai city still has low interest to visit. Binjai has a public library, but the conditions regarding facilities and building appearance are required to be improved. The library still not be able to provide a reading facility to all levels of its community, children, and adults. Right now, the public library in Binjai still using a simple way of operational and structuring and also less comfortable with utilization.

Services and facilities provided by the library must be well organized and run professionally so that they can encourage people to improve their ability to search and find information [4]. Based on this, Binjai needs a public library with complete facilities and interior quality, supporting facilities and infrastructure by the standards of a library and the appearance of buildings so that it can attract the public to visit the library.

\section{Literature Review}

Public Library

The library is an institution to manage collections such as paperwork, printed work, and/ recorded works professionally using a standard system to fulfill education requirements, research, preservation, information, and recreation of the visitors [5].

One type of library that can be accessed easily by the public is a public library. The public library is a very democratic educational institution because it provides learning resources according to people's needs without distinguishing race, religion, gender, social background level, level of age and educational background, and any other differences [6].

The library building has space consists of the number of rooms that each of them has different functions. The room that prepared by the library must separate from other activity. Besides room separation also to adjust the nature of activity, activity system, number of users, number of staff, and security of work procedures, so that activities carried in the library run effectively [7].

A public library is divided into several categories of space, namely collection space, staff workspace, and supporting room. The collection room consists of several collections of age groups, such as collection rooms for children, teenagers, and adults. Also, collections such as reference collections (references), magazines, newspapers, audiovisual collections, and digital library collections (digital libraries). The office workspace is divided based on the types of services provided in the library. Supporting rooms consist of toilets, warehouses, lobbies, showrooms, and meeting rooms [8]. 
Theme

The theme used in building construction is metaphorical architecture. Charles Jencks contends that "People invariably see one building in terms of another, or terms of a similar object, in short as a metaphor" [9]. Building observers can freely interpret an architectural object so that they may have their respective perceptions of the building. There are three categories of metaphors are an abstract metaphor (intangible metaphor), a real metaphor (tangible metaphor), and a combination metaphor [10].

One of the examples application of metaphorical architecture in the design of public libraries by an analogy of book form as the metaphor. The book selected as a metaphor of the library as an interpretation of library buildings and activities carried out in by its function as a library that provides reading facilities in the form of books.

\section{Method}

The method used to design the building using a comparative study of literature by collecting information/data design of a public library includes the themes taken from various sources (books, internet, etc.). Other methodologies used by interviewing the Binjai library manager to collect non-physical data such as the data number of visitors, library facilities, etc. The Interview also conducted at the Indonesian Malay Cultural Council (MABMI) in the city of Binjai to collect information about local heritage as a source of local culture, especially Malay culture.

There are several criteria for the designer choosing the location. The location like Jalan Letjend Jamin Ginting as the main road, near to the downtown and easy people to access. Besides that, the chosen location is also near to educational facilities, such as schools and universities (Figure $1)$.

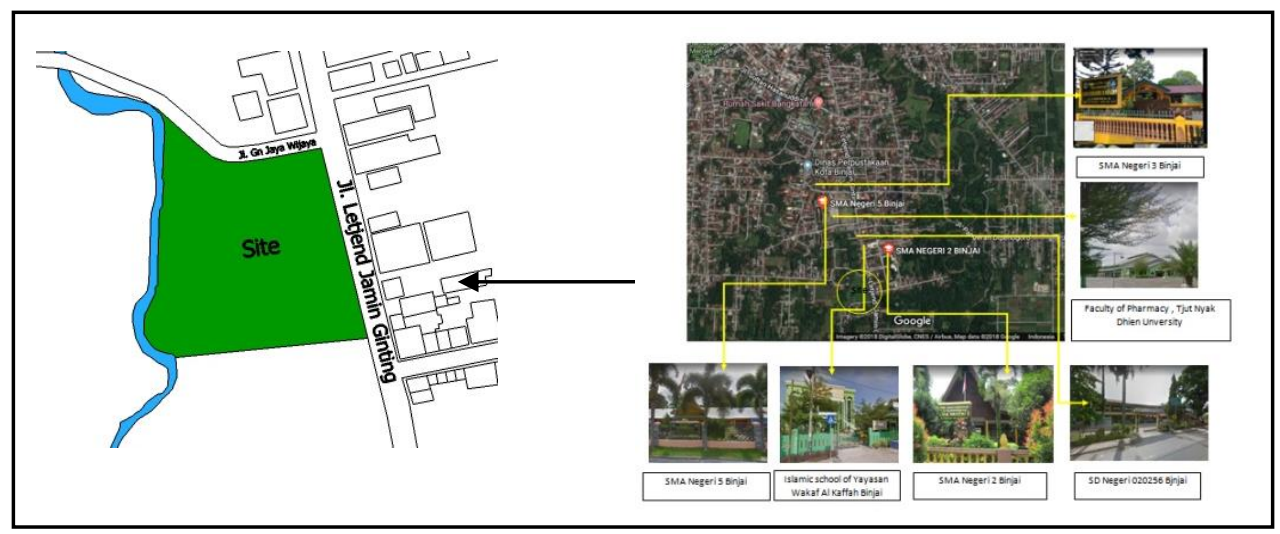

Figure 1. Location of the Design 


\section{Results and Discussion}

Location of the design on the road of Letjend Jamin Ginting, West Binjai, Binjai, North Sumatra with land ownership status as private property. It is bordered by houses in the north and east direction and borders with tributaries to the west. The distance from the library to the center of Binjai city is about $\pm 2.5 \mathrm{~km}$ and also can be accessed by public transportation for around 10 minutes.

\subsection{Basic Form}

The building's basic form concept is based on the site analysis and the application of metaphorical themes applied to buildings. The shape of the building is inspired by a compiled book (Figure 2). The basic form itself is a representation of tangible metaphor and intangible metaphor (combined metaphor) themes. The tangible metaphor concept can be seen starts from the form of a book arranged randomly on the wings of the building, the form of a neatly book arrangement on the main part of the building, and the open form of the book at the entrance building. The intangible metaphor applied to all parts of book representation from the bookentry process to the library. First, the book distributed to the library in the form of the unarranged book, then the book will be arranged in a collection room and finally can be accessed and read by the readers.

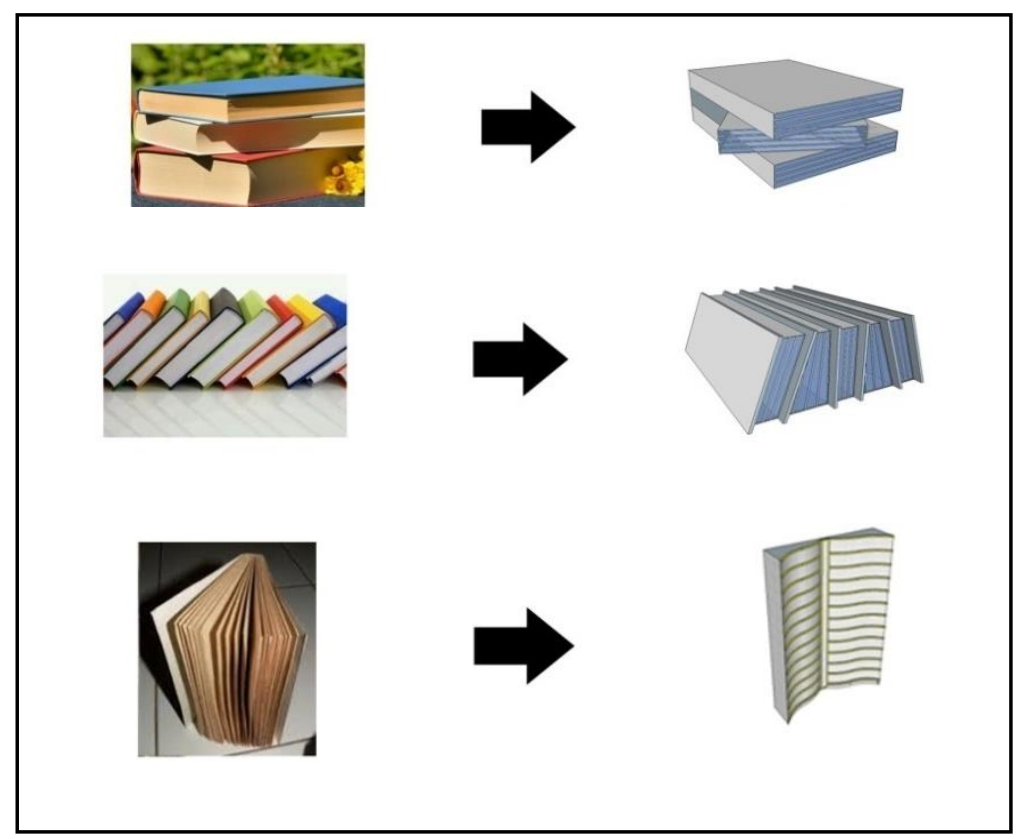

Figure 2. The Basic Form of the Mass

There are several design steps that frequently used to bring light into the room by preparing the upper and side opening [11]. The mass of the building is made extending north and south to maximize the opening on the north and south sides of the building and minimize the east and west sides of the building to minimize heat radiation on the east-west side (Figures $3 \& 4$ ). 


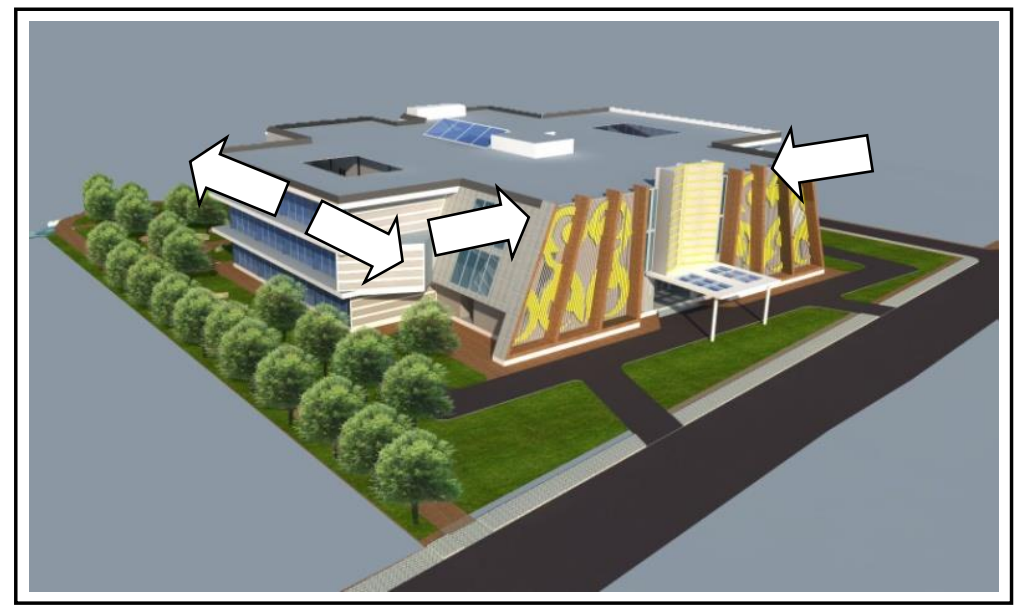

Figure 3. Building Mass Concept

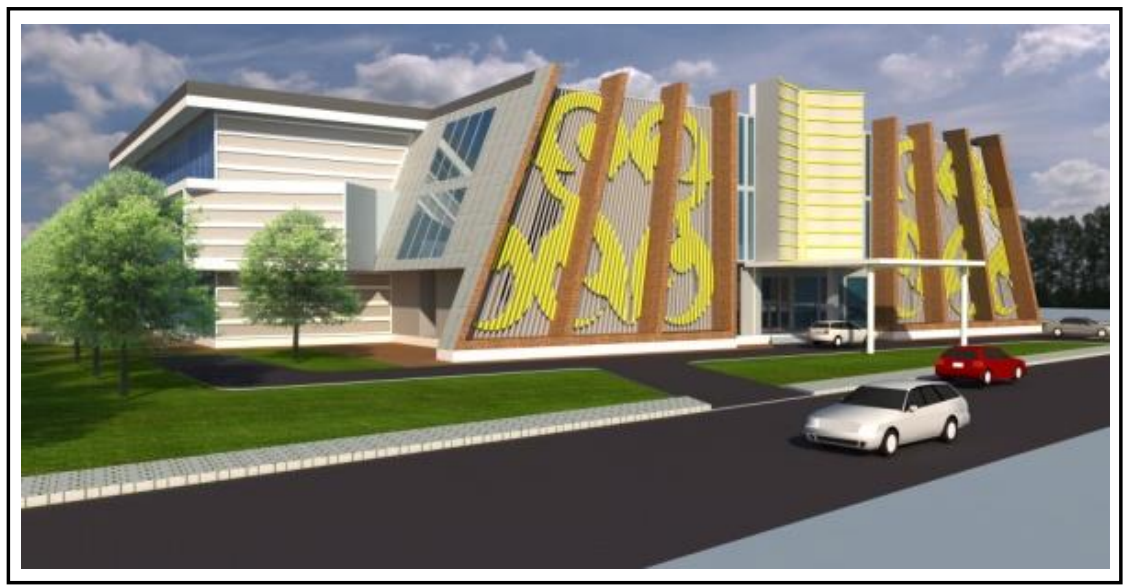

Figure 4. Building Perspective

\subsection{Landscape}

The entrance area placed on the Main Street side (Jl. Letjend. Jamin Ginting) to ease vehicles passing through. Service area placed on Jl. In Gn. Jaya Wijaya, as this area is not quite busy. Circulation differed between vehicle and pedestrian. Access of vehicles and pedestrians is separated to avoid crossing (Figure 5). 


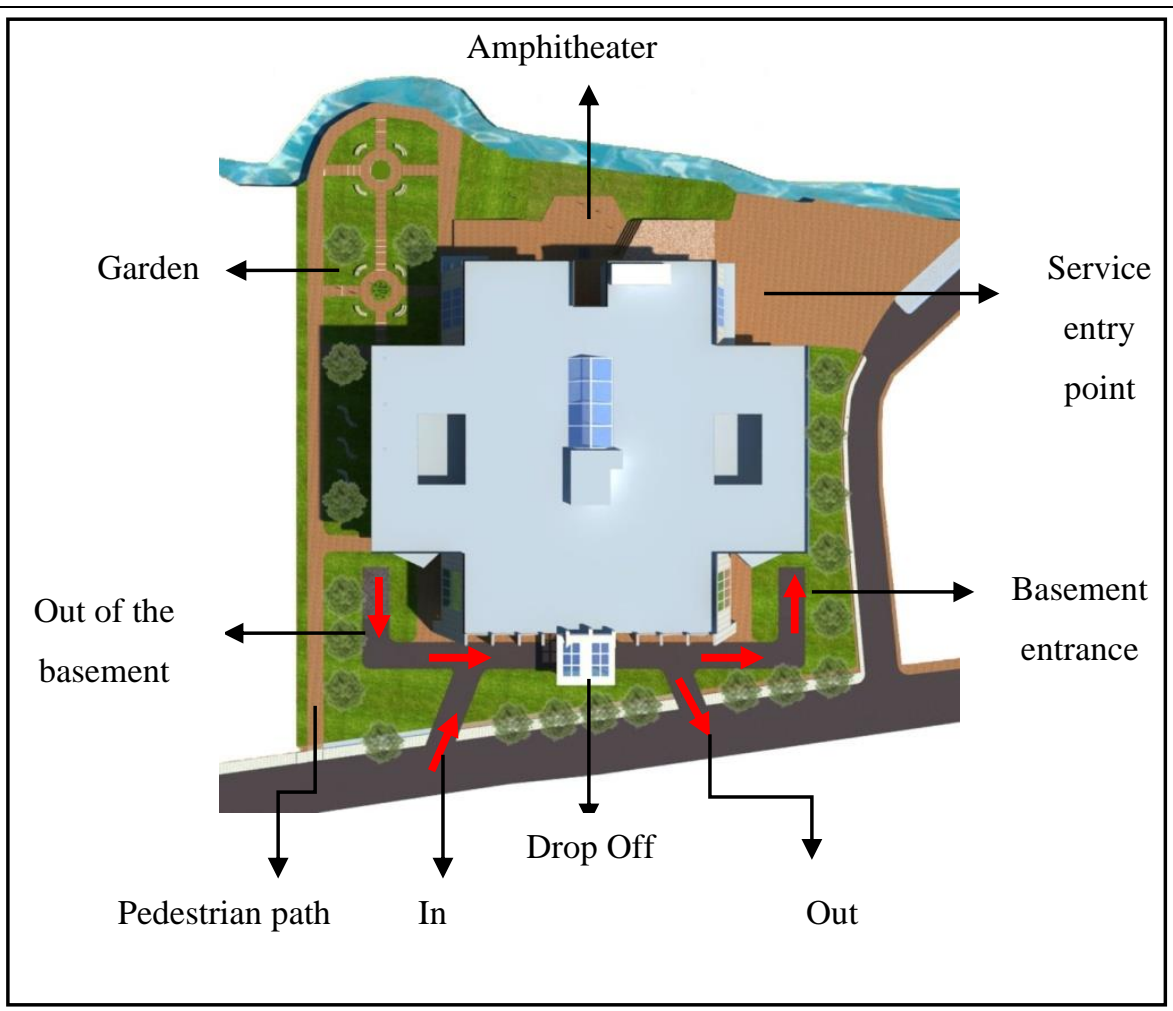

Figure 5. Site Design Concept

There is an amphitheater as communal space placed directly adjacent to the river. It can be a communal space used for various activities such as outdoor reading space, culture festival, library routine activities (reading/storytelling), etc. (Figure 6).

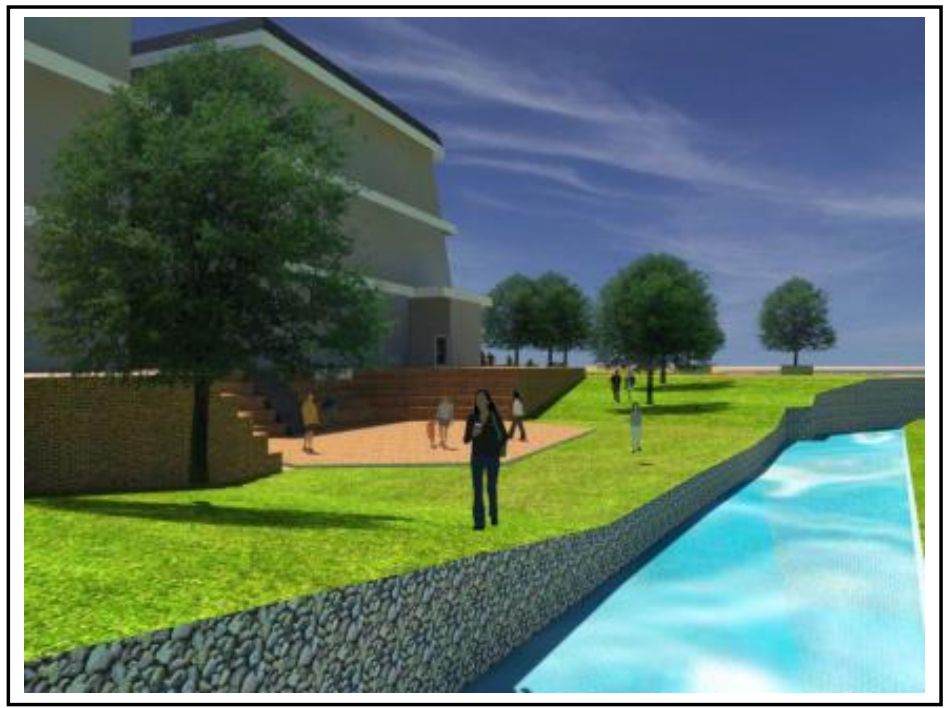

Figure 6. Communal Space

\subsection{Facade}

Secondary skin is used to reduce the heat of sunlight at the east side of the building and become a representation form of sheets of paper in a book. Malay motifs (Itik Sekawan) also used as a representation of duck nature behavior walking in line while they went home. Duck's nature 
behavior reflected images of Binjai people who always hand in hand, friendly, together with willing to preserve the culture of the local heritage (Figure 7).

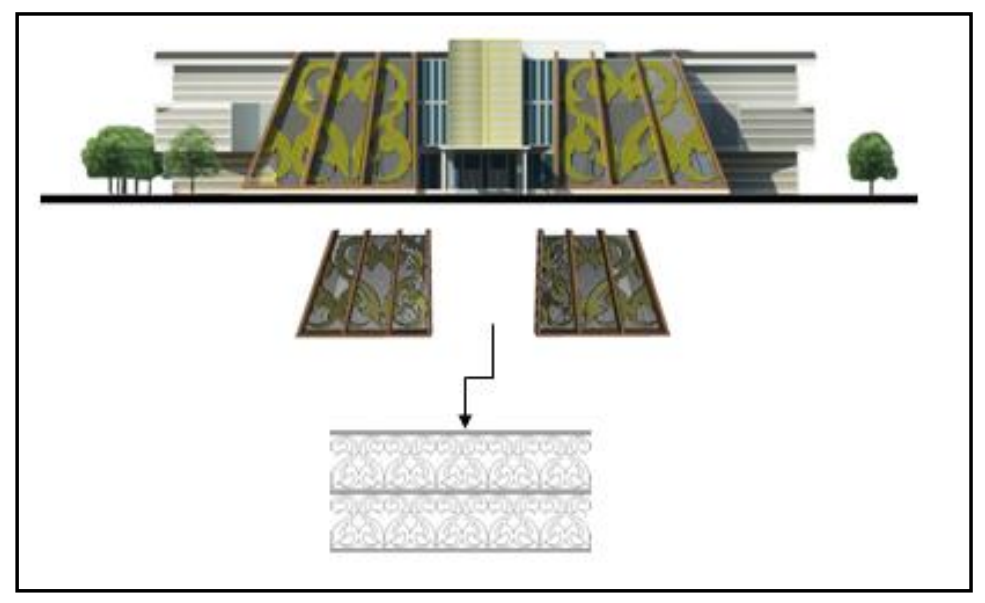

Figure 7. Facade Concept

\subsection{Interior Design}

The concept of the library is indoor and outdoor reading rooms (Figure 8). Visitors can read both indoors and outdoor reading area. The usage of outdoor reading rooms not only as voids in the center of the building and natural lighting but can also be a response to the conditioning area by cooling down the temperature of the building.

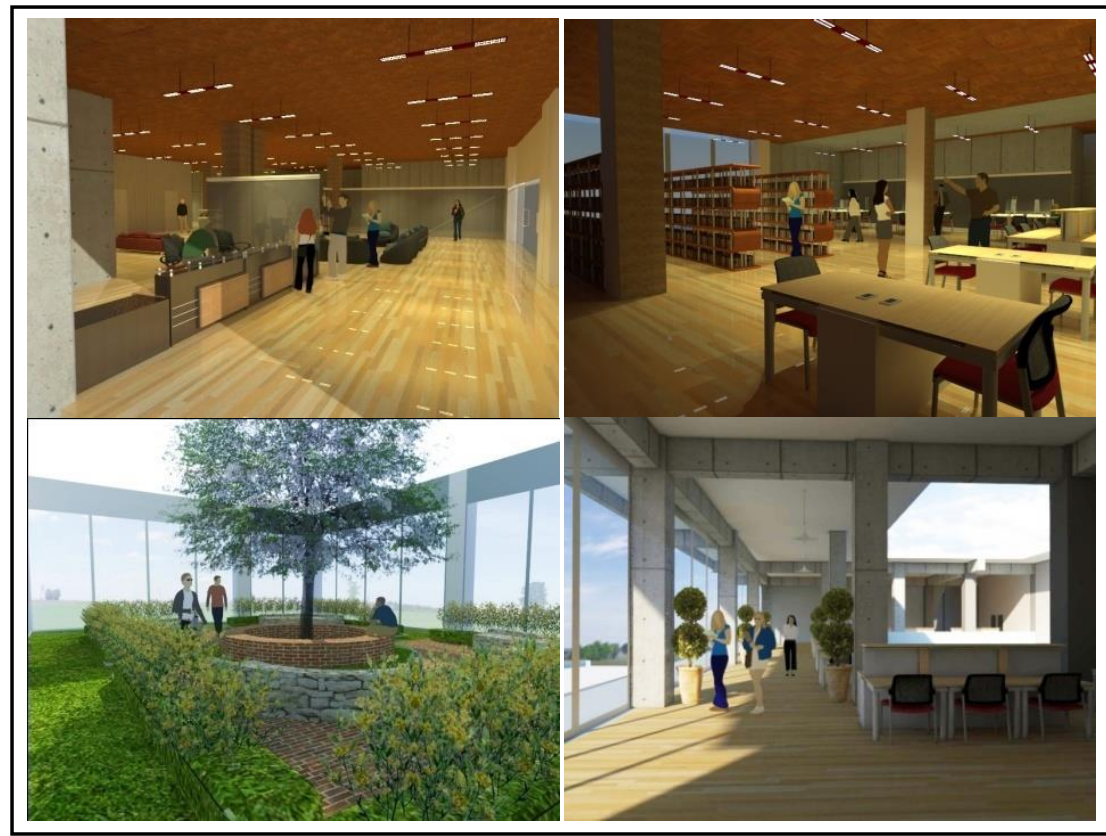

Figure 8. Interior Perspective 


\subsection{Zoning}

Zoning in the interior space is divided into public zones, semi-public zones, service zones, and private zones (Figure 9).

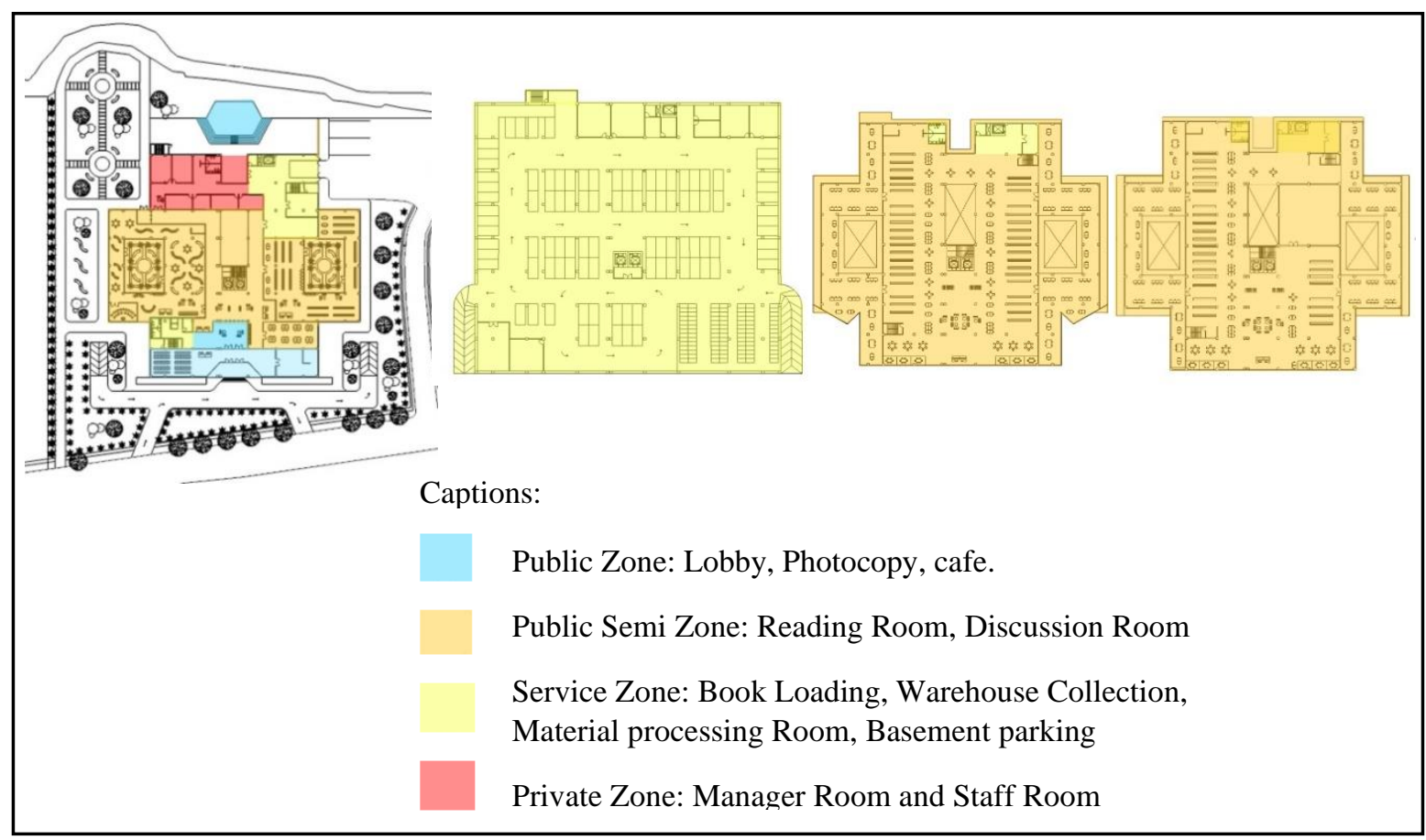

Figure 9. Design Zoning

\section{Conclusions}

Binjai City Public Library designing located on Jl. Letjend Jamin Ginting. This library prioritizes facilities and infrastructure to support the function of the building as a public library. The function of the library is not only as a place to providing books but also as a place for community recreation and as a forum supporting local cultural activities.

The concept used in the design of the Binjai City Public Library is a concept formed by using metaphorical themes in buildings. The theme used in this building is a type of combined metaphor, taking interpretation from the book. The concept design of space Binjai City Public Library is applied to accommodate library services and activities. By taking a representation of the physical form of the book as part of the building construction, giving all facilities and services can be functioned to attract more people's attention to visit the library.

\section{Acknowledgment}

Praise God Almighty, for the presence of plenty of mercy and his grace, so that the author can complete this journal. The author also expressed gratitude to the Department of Architecture, Universitas Sumatera Utara, which is provided insight and expertise that greatly assisted the research. 


\section{REFERENCES}

[1] E. Kartika, "Memacu Minat Baca Siswa Sekolah Dasar," Jurnal Pendidikan Penabur, vol. 3, pp. 113-128, 2004.

[2] Abraham, Dampak Perpustakaan Keliling terhadap Kebiasaan Membaca Masyarakat di Kotamadya Kendari Propinsi Sulawesi Tengah (Thesis), Universitas Gajah Mada, 1998.

[3] E. Sutrisno, Manajemen Sumber Daya Manusia, Jakarta: Kencana, 2009.

[4] P. Gill, The Public Library Service: IFLA/UNESCO Guidelines for development, Netherlands: IFLA and Institution Publication, 2001.

[5] S. Basuki, Pengantar Ilmu Perpustakaan, Jakarta: PT Gramedia Pustaka Utama, 1991.

[6] S. Ns, Perpustakaan dan Masyarakat, Jakarta: Yayasan Obor Indonesia, 2003.

[7] P. N. RI, Pedoman Umum penyelenggaraan Perpustakaan Umum, Jakarta: Perpustakaan Nasional RI, 2000.

[8] P. N. R. Indonesia, Pedoman Tata Ruang dan Perabot Perpustakaan Umum, Jakarta: Perpustakaan Nasional Republik Indonesia, 2009.

[9] C. Jencks, The Language of Post-Modern Architecture, London: Academy Editions and New York: Rizzoli, 1960.

[10] A. C. Antoniades, Poethics of Architecture, New York: Van Nostrand, 1990.

[11] N. Lechner, Heating, Cooling, Lighting: Design Method For Architect, Canada: John Wiley \& Sons, Inc, 1968. 